\title{
KAJIAN MAKNA SISTEM STRUKTUR PADA RUMAH LAMIN
}

\author{
Faizal Baharuddin ${ }^{1}$, Mohammad Mochsen Sir ${ }^{2}$, Abdul Mufti Radja ${ }^{3}$ \\ 1.Laboratorium Teori, Sejarah, Universitas 17 Agustus 1945 Samarinda, \\ Jl. Ir. H. Juanda No. 80, Kota Samarinda, Kalimantan Timur \\ 2,3.Laboratorium Teori, Sejarah dan Arsitektur Perilaku, Program Studi Arsitektur, Fakultas Teknik, \\ Universitas Hasanuddin, \\ Jl. Poros Malino Km.6, Bontomarannu, Kabupaten Gowa, Sulawesi Selatan \\ Email: ${ }^{1}$ f4ical.fb@gmail.com, ${ }^{2}$ sirmochsen@gmail.com, ${ }^{3}$ mufti@yahoo.com
}

\begin{abstract}
Abstrak
Tujuan penulisan artikel ini adalah untuk mengungkap sistem struktur dan makna dari struktur rumah Lamin yang merupakan bentuk kearifan lokal arsitektur tradisional. Obyek studi adalah adalah rumah Lamin di Desa Pampang Kota Samarinda. Rumah tersebut masih mengacu pada prinsip arsitektur tradisional seperti terdapat simbol atau analogi manusia seperti kepala, badan dan kaki. Metode penelitian adalah deskriptif kualitatif dan berdasarkan pada pendekatan interpretatif dengan menggunakan teknik wawancara terhadap sistem struktur yang terkandung makna. Hasil penelitian adalah sistem struktur rumah Lamin terdiri struktur bawah (sukaq), struktur atas (sulo) dan struktur atap (sapau). Makna yang terkandung dari setiap elemen struktur tersebut memberikan gambaran bahwa dalam struktur sukaq ada kekuatan dukungan alam dan lingkungan terhadap manusia, struktur sulo menggambarkan terciptanya hubungan kekerabatan yang erat antara manusia, serta struktur sapau memberikan makna adanya hubungan manusia dengan alam gaib. Kearifan lokal yang terkandung di dalam arsitektur tradisional diharapkan mampu memberikan sumbangan bagi perkembangan ilmu arsitektur dunia.
\end{abstract}

Kata kunci: arsitektur tradisional, makna, kearifan lokal.

\section{Abstract}

\section{Title: Meaning Studies of Structural System in Lamin Houses}

This article aims to reveal the structural system and meaning of the Lamin house structure, a form of local wisdom of traditional architecture. The object of study is the Lamin house in Pampang Village, Samarinda City. The house still refers to traditional architectural principles such as human symbols or analogies such as the head, body, and legs. The research method is descriptive qualitative and based on an interpretive approach using interview techniques to the structural system that contains meaning. The results of the research are the Lamin house structure system consisting of a lower structure (sukaq), an upper structure (sulo), and a roof structure (sapau). The meaning contained in each of these structural elements illustrates that in the sukaq structure there is the power of natural and environmental support for humans, the sulo structure demonstrates the creation of a close kinship between humans, and the construction of sapau gives meaning to the existence of human relations with the supernatural. Local wisdom contained in traditional architecture is expected to be able to contribute to the enrichment of the world architectural knowledge.

Keywords: traditional architecture, meaning, local wisdom.

\section{Pendahuluan}

Rumah sebagai pembentuk peradaban manusia merupakan ilmu pengetahuan yang perlu dipertahankan, terlebih rumah tradisional merupakan salah satu bentuk budaya nusantara. Peradaban dan kebudayan mempunyai elemen ide, gerak dan artefak, lebih lanjut menurut Koentjaraningrat (1998) kebudayaan adalah keseluruhan sistem gagasan, tindakan, dan hasil karya manusia dalam rangka kehidupan masyarakat yang dijadikan milik diri manusia dengan belajar. Bahwa kebudayaan memberikan pengaruh luas terhadap perkembangan ilmu pengetahuan dan teknologi. Menurut Marcus (2006), sebuah rumah tidak hanya sebagai tempat melakukan aktivitas domestik dan aktivitas budaya, akan tetapi juga sebagai sarana utnuk menunjukkan ekspresi personal pemiliknya. Kemajuan teknologi dan gaya 
hidup baru yang diadopsi dari budaya luar telah mempengaruhi tata atur ruang pada rumah tradisional. Pada keberadaan rumah tradisional dengan berbagai proses pembentuknya terdapat banyak informasi yang menjadi referensi pengetahuan dalam bidang arsitektur termasuk sistem struktur yang terbentuk.

Struktur bangunan pada umumnya terdiri dari struktur bawah dan struktur atas. Setiap komponen tersebut memiliki fungsi yang berbeda-beda di dalam sebuah struktur, tidak terkecuali arsitektur Lamin. Menurut Kusuma dan Andriono (1993), perencanaan struktur yang tepat dan teliti dapat memenuhi kriteria kekuatan (strength), kenyamanan (serviceability), keselamatan (safety) dan umur rencana bangunan (durability) beban-beban yang bekerja pada struktur seperti beban mati (dead load), beban hidup (liveload), beban gempa (earthquake) dan beban angin (wind load) menjadi bahan perhitungan awal dalam perencanaan struktur untuk mendapatkan besar dan arah gaya-gaya yang bekerja pada setiap komponen struktur.

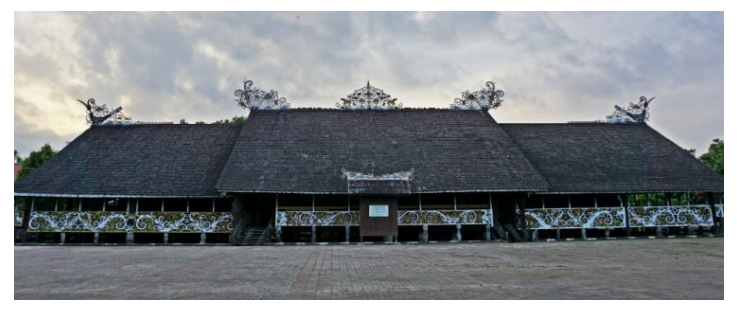

Gambar 1. Arsitektur tradisional Dayak - rumah Lamin

Sumber: Dokumentasi lapangan, 2019

Arsitektur tradisional Dayak salah satunya Lamin (rumah), memiliki keunikan selain terdapat ruang privasi yang digunakan bersama, juga sistem struktur yang mengandung makna. Arsitektur Lamin Dayak Kenyah yang terdapat di Desa Pampang Kota Samarinda, juga sebagai simbol budaya menjadi obyek observasi dalam penelitian ini. Ruangan di dalam Lamin terdiri dari pagen berfungsi sebagai teras untuk para pria, dalem amin berfugsi sebagai ruang berkumpul, tilong berfungsi sebagai ruang tidur orang tua dan anak gadis, serta atang sebagai tempat menyimpan air dan memasak.

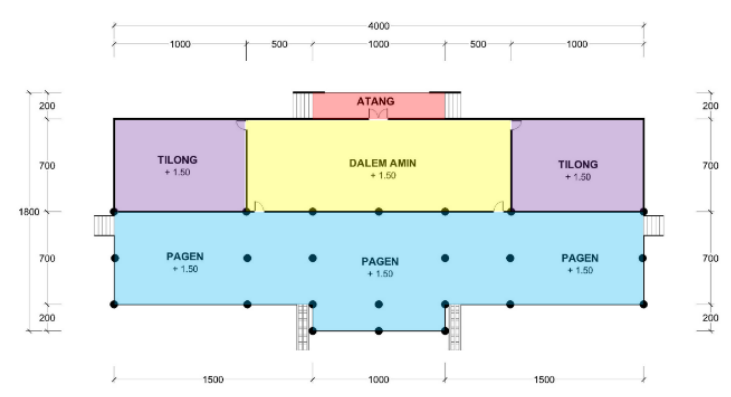

Gambar 2. Denah Rumah Lamin

Sumber: Gambar rekonstruksi hasil survey lapangan, 2019

Pada umumnya struktur rumah tradisonal ataupun bangunan modern memiliki sistem yang hampir serupa. Selain mengantisipasi kondisi iklim, struktur panggung rumah Lamin juga berfungsi sebagai tempat pertahanan dari serangan binatang buas maupun serangan dari suku lain, kolong rumah panggung ini biasanya juga difungsikan sebagai kandang babi dan beberapa ekor anjing yang biasa digunakan sebagai sensor keamanan dan dapat membantu dalam berburu. Tangga naik ke rumah Lamin dibuat dari batang kayu yang utuh, dimana satu sisi dibentuk anak tangga dan sisi satunya tetap silinder. Jika siang hari sisi anak tangga dibuat menghadap ke atas sebagai sarana naik-turun bagi penghuninya, namun pada malam hari posisinya dibalik sehingga sisi silinder yang berada di atas. Dengan demikian, binatang merayap seperti ular tidak bisa naik ke Lamin.

Berdasarkan fenomena di atas, maka perumusan masalah kajian ini adalah menggali sistem struktur dan makna yang terkandung struktur pada rumah Lamin. Tujuan penelitian adalah untuk mengungkapkan sistem struktur dan maknanya sebagai sebagai bentuk temuan kearifan lokal arsitektur tradisional Dayak. Manfaat kajian ini adalah arsitektur tradisional dapat menjadi pengembangan ilmu arsitektur sesuai dengan nilai lokalitasnya. 


\section{Metode}

Pendekatan yang digunakan dalam penelitian adalah kualitatif dengan metode naratif deskripitf. Menurut Sukmadinata (2009), penelitian kualitatif adalah penelitian yang digunakan untuk mendeskripsikan dan menganalisis fenomena, peristiwa, aktivitas sosial, sikap, kepercayaan, presepsi, dan orang secara individual maupun kelompok. Lebih lanjut proses analisis makna dengan menggunakan makna konotatif dan denotatif.

Zgusta (1971) berpendapat makna konotatif adalah makna semua komponen pada kata ditambah beberapa nilai mendasar yang biasanya berfungsi menandai. Makna denotatif adalah makna dalam alam wajar secara eksplisit. Makna wajar ini adalah makna yang sesuai dengan apa adanya. Denotasi adalah hubungan yang digunakan di dalam tingkat pertama pada sebuah kata yang secara bebas memegang peranan penting di dalam ujaran (Lyons, J., 1977:208). Makna denotasi sering juga disebut makna dasar, makna asli, atau makna pusat. Dari beberapa pengertian di atas dapat disimpulkan bahwa makna denotatif adalah makna fisik dan makna konotatif adalah makna metafisik.

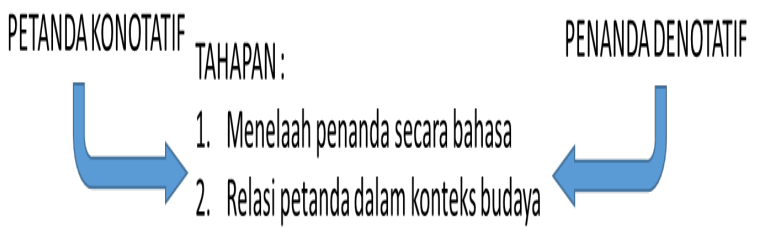

Gambar 3. Bagan makna denotatif dan konotatif Sumber: Analisis peneliti, 2019

\section{Hasil dan Pembahasan}

\section{Identifikasi Sistem Struktur Rumah Lamin}

Identifikasi ini dilakukan berdasarkan hasil survey dan wawancara dengan pengelola rumah Lamin yaitu bapak Lang Alang (48 tahun) untuk mendapatkan beberapa pengertian dari struktur rumah Lamin yang ada di Desa Pampang, dengan lokasi desa berjarak $23 \mathrm{~km}$ dari pusat Kota Samarinda.
Pada lokasi ini orang Dayak Kenyah mulai bermukim di daerah Pampang sekitar tahun 1960-an (Nasrullah, M.A., 2017).

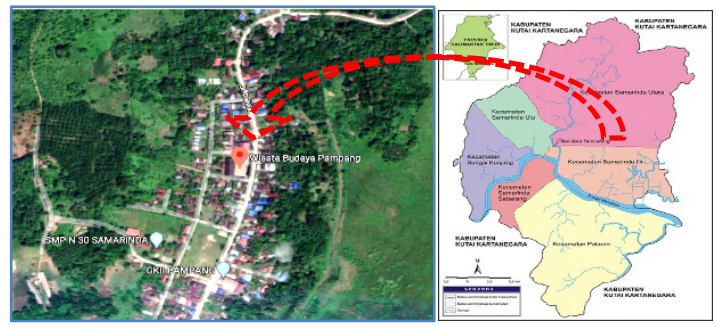

Gambar 4. Lokasi rumah Lamin di Desa Pampang Kota Samarinda Sumber: Google Map, 2019

Tabel 1. Elemen sistem struktur

\begin{tabular}{|c|c|c|}
\hline \multirow{2}{*}{$\begin{array}{l}\text { Elemen } \\
\text { Struktur }\end{array}$} & \multicolumn{2}{|c|}{ Identifikasi } \\
\hline & Tangibel & Intagbibel \\
\hline $\begin{array}{l}\text { Struktur } \\
\text { Bawah }\end{array}$ & $\begin{array}{l}\text { Struktur bawah } \\
\text { memikul beban-beban } \\
\text { dari struktur di } \\
\text { atasnya sehingga } \\
\text { struktur bawah tidak } \\
\text { boleh runtuh terlebih } \\
\text { dahulu dari struktur } \\
\text { atas. Ibarat manusia, } \\
\text { kaki adalah struktur } \\
\text { bawahnya. Jika kaki } \\
\text { tersebut patah (runtuh) } \\
\text { maka orang tersebut } \\
\text { akan sulit untuk } \\
\text { berdiri. }\end{array}$ & $\begin{array}{l}\text { Sebagai penopang semua } \\
\text { beban di atas, struktur } \\
\text { bawah menjadi simbol } \\
\text { memikul atau } \\
\text { mendukung semua } \\
\text { kegiatan di atasnya, serta } \\
\text { sebagai penghubung } \\
\text { antara rumah Lamin } \\
\text { dengan alam (tanah). } \\
\text { (ALAM) }\end{array}$ \\
\hline $\begin{array}{l}\text { Struktur } \\
\text { Atas }\end{array}$ & $\begin{array}{l}\text { Struktur atas adalah } \\
\text { seluruh bagian } \\
\text { struktur gedung yang } \\
\text { berada di atas muka } \\
\text { tanah. Struktur atas ini } \\
\text { terdiri atas kolom, } \\
\text { balok, dinding geser } \\
\text { dan tangga, yang } \\
\text { masing-masing } \\
\text { mempunyai peran } \\
\text { yang sangat penting. }\end{array}$ & $\begin{array}{l}\text { Struktur atas memiliki } \\
\text { simbol sebagai badan } \\
\text { dari Lamin. Badan } \\
\text { memiliki makna sebagai } \\
\text { tempat ruh dari Lamin } \\
\text { tersebut. (MANUSIA) }\end{array}$ \\
\hline $\begin{array}{l}\text { Struktur } \\
\text { Atap }\end{array}$ & $\begin{array}{l}\text { Atap merupakan } \\
\text { bagian dari struktur } \\
\text { bangunan yng } \\
\text { berfungsi sebagai } \\
\text { penutup/ pelindung } \\
\text { bangunan sehingga } \\
\text { memberikan } \\
\text { kenyamanan bagi } \\
\text { pengguna bangunan. } \\
\text { Struktur atap pada } \\
\text { umumnya terdiri dari } \\
\text { tiga bagian utama, } \\
\text { yaitu: struktur penutup } \\
\text { atap, gording dan } \\
\text { rangka kuda-kuda. }\end{array}$ & $\begin{array}{l}\text { Struktur atap merupakan } \\
\text { simbol untuk melindungi } \\
\text { gangguan dari atas, serta } \\
\text { memliki makna pula } \\
\text { sebagai tempat } \\
\text { beradanya alam gaib. } \\
\text { (GAIB/DEWA/TUHAN) }\end{array}$ \\
\hline
\end{tabular}

Sumber: Analisis peneliti, 2019

Sistem struktur rumah Lamin dibagi menjadi 3 bagian, yaitu struktur atap, struktur atas 
dan struktur bawah, seperti yang dijelaskan pada gambar isometri di bawah ini.

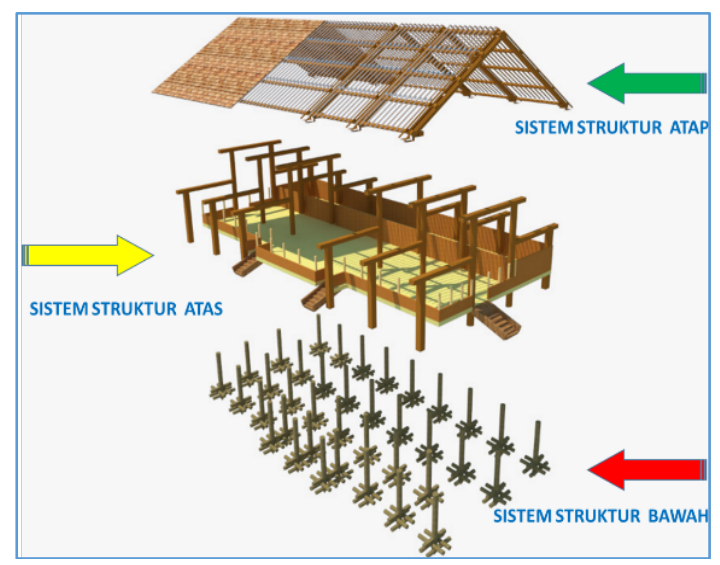

Gambar 5. Isometri sistem struktur Sumber: Analisis peneliti, 2019

Hasil elaborasi terkait pengertian dari masing-masing istilah pada sistem struktur rumah Lamin yang ada di Desa Pampang adalah sebagai berikut:

1. Sukaq Epek adalah tiang pondasi dasar untuk menopang balok lantai (dasei), dimana sebagian tertanam di dalam tanah dan sebagian berada di atas tanah yang terdiri dari:

a. Sunduk adalah balok pengunci dengan panjang ukuran $20 \mathrm{~cm}-40$ $\mathrm{cm}$.

b. Kalang adalah balok atau papan melintang dengan panjang $>5 \mathrm{~m}$.

2. Sukaq Solai adalah tiang utama dengan bentuk bulat yang berasal dari kayu ulin dengan diameter $30 \mathrm{~cm}-50 \mathrm{~cm}$, posisi tertanam ke dalam tanah $\pm 2 \mathrm{~m}$ sampai ke atas atap. Panjang sukaq utama antara 10 $\mathrm{m}-12 \mathrm{~m}$.

3. Sukaq adalah tiang/ kolom sebagai penopang ruang, sukaq terbuat dari kayu ulin dengan ukuran/ diameter $10 \mathrm{~cm}-12$ $\mathrm{cm}$.

4. Sulo adalah balok utama dari kayu ulin dengan ukuran $\pm 6 / 12 \mathrm{~cm}$ yang menghubungkan atau mengikat antara sukaq epek dengan sukaq epek.

5. Ladeng Aso atau biasa disebut balok gelagar adalah balok lantai dengan ukuran $5 / 10 \mathrm{~cm}$ atau $6 / 12 \mathrm{~cm}$ bertumpu pada balok utama dengan jarak $50 \mathrm{~cm}$.

6. Sukaq Ba'a adalah tiang penopang dinding utama.
7. Sulo Da'a adalah balok pengikat antara sukaq ba'a dengan sukaq ba'a yang lain atau lebih dikenal dengan ringbalk.

8. Sekang adalah balok ulin dengan ukuran $6 / 12 \mathrm{~cm}$ berfungsi sebagai struktur utama kuda-kuda penopang atap.

9. Kang adalah istilah sambungan kayu yang digunakan untuk semua sambungan baik sukaq, sulo dan da'a.

10. Sapau adalah atap yang menggunakan bahan sirap (papan tipis dari kayu ulin).

11. Kasoa adalah bagian dari kuda-kuda.

Di bawah ini merupakan gambaran letak dan posisi sistem struktur rumah Lamin.

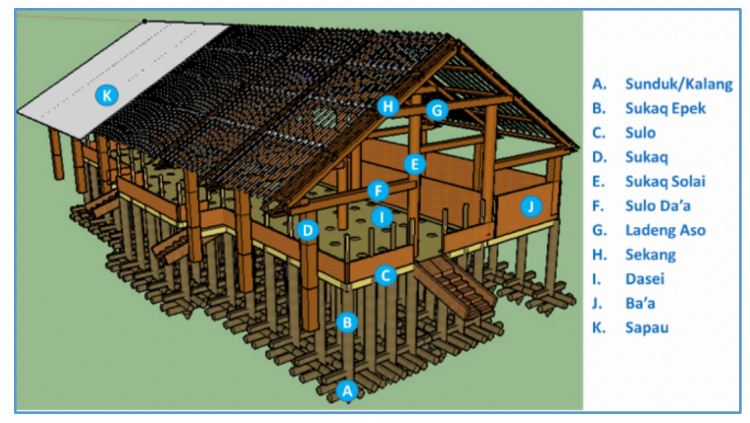

Gambar 6. Isometri keterangan sistem struktur Sumber: Analisis peneliti, 2019

Struktur bawah yang bertindak sebagai pondasi terdiri atas kolom-kolom kayu yang terbagi dalam 2 jenis fungsi, yakni sukaq epek untuk kolom bawah rumah dengan diameter $10 \mathrm{~cm}$ (terletak pada grid bagian bawah) yang berfungsi sebagai tiang penyangga utama, dan sunduk/ kalang untuk penyangga sukaq epek dengan diameter $5 \mathrm{~cm}$ yang ditempatkan di sisi paling bawah dari kolom-kolom pondasi rumah.

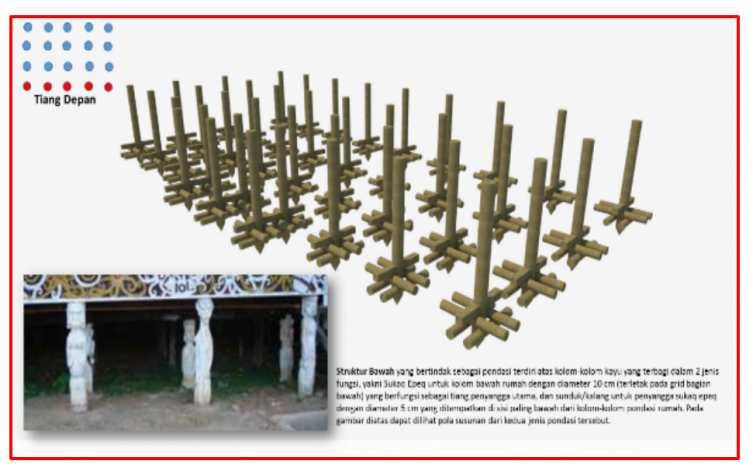

Gambar 7. Struktur sukaq epek Sumber: Analisis peneliti, 2019 
Struktur balok lantai sebagai penopang lantai (dasei) dan didukung struktur sukaq epek. Dengan menggunakan sistem tumpang, dimana struktur ladeng aso di dudukkan di atas struktur sulo.

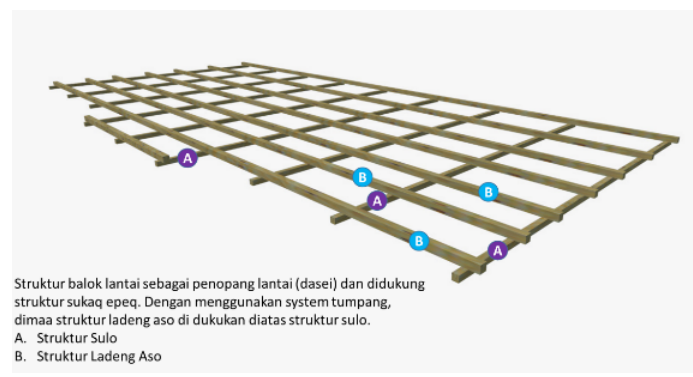

Gambar 8. Struktur sulo \& ladeng aso Sumber: Analisis peneliti, 2019

Badan rumah terdiri atas susunan lantai seperti yang dijelaskan pada gambar di atas dan juga batang-batang kayu yang berfungsi sebagai dinding pada tiap sisi dari rumah Lamin tersebut. $B a$ ' $a$ adalah dinding rumah yang terbuat dari kulit kayu, dimana hampir sebagian besar menggunakan kulit kayu ulin. Sedangkan dasei adalah lantai yang terbuat dari papan ulin dan sebagian menggunakan rotan. Sekang adalah tiang kayu sebagai pengaku dinding $b a^{\prime} a$.

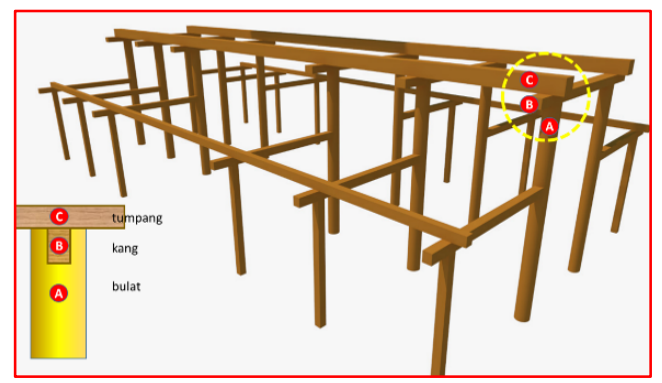

Gambar 9. Struktur sukaq solai

Sumber: Analisis peneliti, 2019

Konstruksi atap Lamin ditopang oleh sukaq solai (tiang bulat utama) yang berjumlah 12 buah. Jumlah ini merupakan simbol adanya pengaruh kekuatan yang berasal dari lingkungan dan para leluhur. Dalam konsep ini, rumah dianggap berada di antara hulu dan hilir sungai (Lamin melintang), tempat yang dianggap mengandung getaran magis yang sangat tinggi.

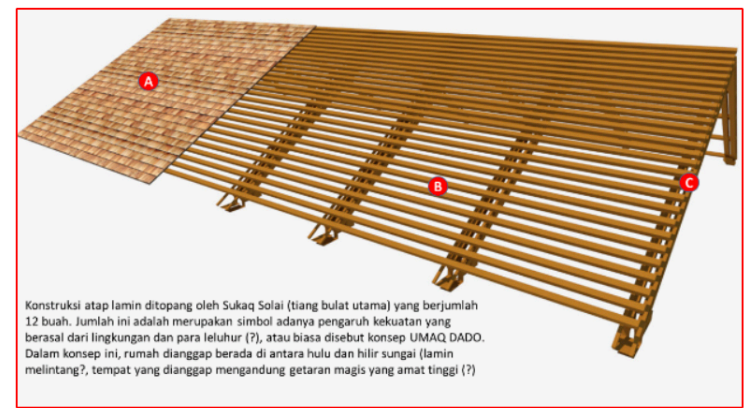

Gambar 10. Struktur sapao

Sumber: Analisis peneliti, 2019

\section{Makna Denotatif dan Konotatif}

Analisis makna merupakan analisis perbandingan antara makna awal dengan makna yang berubah, baik makna denotatif maupun konotatif. Sebelum sampai pada analisis makna yang mempunyai keterkaitan, perlu membuat pengertian dasar dari istilah sistem struktur.

Tabel 2. Pengertian dasar dan unsur tradisi

\begin{tabular}{|c|c|c|c|}
\hline No & Struktur & $\begin{array}{c}\text { Pengertian } \\
\text { Dasar }\end{array}$ & $\begin{array}{l}\text { Tradisi/ } \\
\text { Budaya }\end{array}$ \\
\hline 1. & $\begin{array}{l}\text { Sukaq } \\
\text { Epek }\end{array}$ & $\begin{array}{l}\text { Tiang pondasi } \\
\text { dasar untuk } \\
\text { menopang } \\
\text { balok lantai } \\
\text { (dasei), } \\
\text { dimana } \\
\text { sebagian } \\
\text { tertanam di } \\
\text { dalam tanah } \\
\text { dan sebagian } \\
\text { berada di atas } \\
\text { tanah. }\end{array}$ & $\begin{array}{l}\text { Simbol } \\
\text { kemanusiaan. } \\
\text { Tiang depan } \\
\text { yang berada } \\
\text { di bawah, } \\
\text { dengan } \\
\text { ukiran } \\
\text { manusia } \\
\text { sebagai } \\
\text { penopang } \\
\text { kehidupan. }\end{array}$ \\
\hline 2. & $\begin{array}{l}\text { Sukaq } \\
\text { Solai }\end{array}$ & 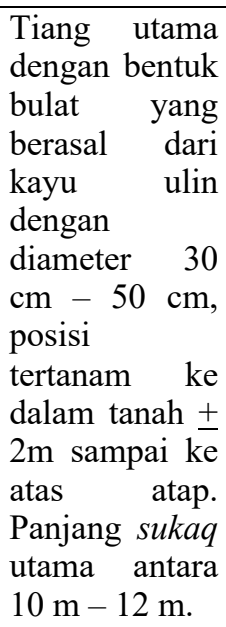 & $\begin{array}{l}\text { Tiang utama } \\
\text { simbol dewa- } \\
\text { dewa dalam } \\
\text { masyarakat } \\
\text { Dayak. } \\
\text { Hubungan } \\
\text { dewa dan } \\
\text { masyarakat. }\end{array}$ \\
\hline 3. & Sukaq & $\begin{array}{l}\text { Tiang/ kolom } \\
\text { sebagai }\end{array}$ & \\
\hline
\end{tabular}




\begin{tabular}{|c|c|c|c|}
\hline & & $\begin{array}{l}\text { penopang } \\
\text { ruang, sukaq } \\
\text { terbuat dari } \\
\text { kayu ulin } \\
\text { dengan } \\
\text { ukuran/ } \\
\text { diameter } \quad 10 \\
\mathrm{~cm}-12 \mathrm{~cm} .\end{array}$ & \\
\hline 4. & Sulo & $\begin{array}{l}\text { Balok utama } \\
\text { dari kayu ulin } \\
\text { dengan ukuran } \\
\pm \quad 6 / 12 \quad \mathrm{~cm} \\
\text { yang } \\
\text { menghubungk } \\
\text { an atau } \\
\text { mengikat } \\
\text { antara sukaq } \\
\text { epek dengan } \\
\text { sukaq epek. }\end{array}$ & \multirow[t]{2}{*}{\begin{tabular}{|l} 
Tiang \\
pendukung, \\
sebagai \\
persatuan \\
masyarakat \\
Dayak. \\
Hubungan \\
lingkungan \\
dan makhluk \\
hidup.
\end{tabular}} \\
\hline 5. & $\begin{array}{l}\text { Ladeng } \\
\text { Aso }\end{array}$ & $\begin{array}{lr}\text { Biasa } & \text { disebut } \\
\text { balok gelagar } \\
\text { adalah balok } \\
\text { lantai dengan } \\
\text { ukuran } 5 / 10 \\
\mathrm{~cm} \text { atau } 6 / 12 \\
\mathrm{~cm} \text { bertumpu } \\
\text { pada balok } \\
\text { utama dengan } \\
\text { jarak } 50 \mathrm{~cm} \text {. }\end{array}$ & \\
\hline 6. & $\begin{array}{l}\text { Sukaq } \\
\text { Ba'a }\end{array}$ & $\begin{array}{l}\text { Tiang } \\
\text { penopang } \\
\text { dinding yang } \\
\text { terbuat dari } \\
\text { kulit kayu. }\end{array}$ & \multirow{2}{*}{$\begin{array}{l}\text { Struktur } \\
\text { pengaku } \\
\text { untuk } \\
\text { material } \\
\text { dinding dan } \\
\text { lantai. } \\
\text { Melindungi } \\
\text { manusia dari } \\
\text { pengaruh } \\
\text { buruk dari } \\
\text { bawah dan } \\
\text { samping. }\end{array}$} \\
\hline 7. & $\begin{array}{l}\text { Sulo Da'a } \\
\text { (Dasei) }\end{array}$ & $\begin{array}{l}\text { Balok } \\
\text { pengikat } \\
\text { antara sukaq } \\
\text { ba'a dengan } \\
\text { sukaq ba'a } \\
\text { yang lain atau } \\
\text { lebih dikenal } \\
\text { dengan } \\
\text { ringbalk. }\end{array}$ & \\
\hline 8. & Sekang & $\begin{array}{l}\text { Balok ulin } \\
\text { dengan ukuran } \\
6 / 12 \quad \mathrm{~cm} \\
\text { berfungsi } \\
\text { sebagai } \\
\text { struktur utama } \\
\text { kuda-kuda } \\
\text { penopang atap. }\end{array}$ & $\begin{array}{l}\text { Sebagai } \\
\text { tameng. } \\
\text { Melindungi } \\
\text { manusia dari } \\
\text { pengaruh } \\
\text { buruk dari } \\
\text { atas. }\end{array}$ \\
\hline
\end{tabular}

\begin{tabular}{|c|c|c|}
\hline 9. & Sapau & $\begin{array}{lr}\text { Atap } & \text { yang } \\
\text { menggunakan } \\
\text { bahan } & \text { sirap } \\
\text { (papan } & \text { tipis } \\
\text { dari } & \text { kayu } \\
\text { ulin). } & \end{array}$ \\
\hline
\end{tabular}

Sumber: Analisis peneliti, 2019

Analisis terhadap makna sistem struktur didasari atas pengamatan di lapangan serta kriteria yang telah diutarakan pada uraian sebelumnya. Dari berbagai kriteria tersebut, maka analisis makna dapat dilakukan. Analisis makna terdiri dari 2 aspek yaitu aspek denotatif (fungsional/ pragmatis) dan aspek konotatif (non-fungsional/non pragmatis). Analisis tersebut dijelaskan melalui tabel berikut ini. 
Tabel 3. Makna denotatif dan konotatif

\begin{tabular}{|c|c|c|c|}
\hline Struktur & Bentuk & Denotatif & Konotatif \\
\hline $\begin{array}{l}\text { Sukaq } \\
\text { Epek }\end{array}$ & & $\begin{array}{l}\text { Balok ulin yang ujungnya runcing } \\
\text { menancap ke tanah dengan diberi } \\
\text { sunduk kalang. }\end{array}$ & $\begin{array}{l}\text { Konteks budaya memberikan } \\
\text { makna bahwa ikatan tanah } \\
\text { dengan kayu sangat kuat, bahwa } \\
\text { antara rumah dan lingkungan } \\
\text { menjadi satu kesatuan. }\end{array}$ \\
\hline $\begin{array}{l}\text { Sukaq } \\
\text { Solai } \\
\text { (Bentuk } \\
\text { Bulat) }\end{array}$ & 0 & $\begin{array}{l}\text { Tiang utama yang berbentuk bulat, } \\
\text { berfungsi sebagai struktur utama } \\
\text { penopang atap. }\end{array}$ & $\begin{array}{l}\text { Bentuk lingkaran } \\
\text { menggambarkan bahwa hidup itu } \\
\text { dinamis. Dia akan berputar dan } \\
\text { bergerak kemanapun kita } \\
\text { mengarahkannya. Ini juga } \\
\text { menggambarkan bahwa hidup } \\
\text { yang baik harus ada keteraturan. }\end{array}$ \\
\hline Sulo & & $\begin{array}{l}\text { Struktur balok lantai atau sulo } \\
\text { merupakan pengikat sukaq epek } \\
\text { dan penopang dasei/ lantai dengan } \\
\text { bentuk grid. }\end{array}$ & \multirow[t]{2}{*}{$\begin{array}{l}\text { Sistem struktur yang berbentuk } \\
\text { persegi panjang memiliki daya } \\
\text { topang yang kuat bagi aktivitas } \\
\text { penghuni yang berjumlah } \\
\text { banyak. }\end{array}$} \\
\hline$B a^{\prime} a$ & & $\begin{array}{l}\text { Bentuk ba'a persegi panjang } \\
\text { sebagai dinding yang berfungsi } \\
\text { sebagai pembatas ruang tidur } \\
\text { dengan ruang lainnya. }\end{array}$ & \\
\hline Sekang & & $\begin{array}{l}\text { Sekang berbentuk segitiga sebagai } \\
\text { struktur utama penopang sapau } \\
\text { atau atap. }\end{array}$ & \multirow[t]{2}{*}{$\begin{array}{l}\text { Makna bentuk segitiga } \\
\text { melambangkan kepercayaan } \\
\text { terhadap perlindungan dewa. }\end{array}$} \\
\hline Sapau & & $\begin{array}{l}\text { Sapau berbentuk segitiga sebagai } \\
\text { penutup atap. }\end{array}$ & \\
\hline
\end{tabular}

Sumber: Analisis peneliti, 2019

\section{Kesimpulan}

Secara umum rumah Lamin memiliki sistem struktur yang menggambaran analogi kepala, badan dan kaki, dimana analogi ini dapat memberikan penjelasan bawah kepala berupa struktur atap atau sapau, badan mewakili struktur atas atau sukaq dan kaki mewakili struktur bawah atau sukaq epek.

Makna konotatif yang terkandung adalah bahwa struktur bawah melambangkan hubungan antara Lamin dengan lingkungannya, sehingga dukungan alam dan lingkungan terhadap kehidupan masyarakat sangat kuat. Kemudian struktur atas memberikan makna hubungan antara manusia yang ada di dalamnya sangat tinggi tingkat kekerabatannya dan sangat terbuka antar masyarakat. Terakhir, struktur atas memberikan gambaran manusia dengan alam gaib, diantaranya bahwa terdapat roh nenek moyang yang masih berdiam di sana serta adanya hubungan yang kuat dengan kekuatan gaib.

\section{Daftar Pustaka}

Koentjaraningrat. (1998). Manusia dan kebudayaan di Indonesia. Jakarta: Djambatan.

Kusuma, G. dan Andriono, T. (1993). Desain struktur rangka beton bertulang di daerah rawan gempa. Jakarta: Erlangga. 
Lyons, J. (1977). Semantics. Cambridge: Cambridge University Press.

Marcus, C.C. (2006). House as a mirror of self: Exploring the deeper meaning of home. Berwick: Nicolas-Hays, Inc.

Nasrullah, M.A. (2017). Lamin Pemung Tawai sebagai wadah pertunjukan seni di Desa Budaya Pampang. Undungga Buletin Pelestarian Cagar Budaya, Volume 6 Tahun 2017.

Sukmadinata, N.S. (2009). Metode penelitian pendidikan. Bandung: Remaja Rosdakarya.

Zgusta, Ladislav. (1971). Manual of lexicography. Praha: Academia. 